\title{
THE MALADIES \\ OF MARY QUEEN OF SCOTS
}

by

SIR ARTHUR MacNALTY, K.C.B.

UNTIL comparatively recently it has not been realized that Mary Queen of Scots from adolescence was a sufferer from peptic ulcer with acute exacerbations and later a cripple from rheumatoid and osteo-arthritis. In addition after the murder of her second husband, Darnley, she had a severe mental and physical breakdown and was not responsible for her actions, being at times in a semimaniacal state. General R.H. Mahon ${ }^{\mathbf{1}}$ first drew attention to her mental collapse; and Dr. Armstrong Davison ${ }^{2}$ in a most interesting paper to the Scottish Society of the History of Medicine which I had the privilege of hearing at Linlithgow in June 1956, has described her maladies and those of her husbands. In my recently published book, Mary Queen of Scots: The Daughter of Debate, ${ }^{3}$ I have endeavoured to show how the Queen's maladies influenced her behaviour and the course of history. The object of this paper is to bring forward some further medical observations on her illnesses, including an account of the treatment which she received for 'chronic rheumatism' at Buxton Spa.

Outline of the Queen's Life

Mary Queen of Scots was born at Linlithgow Palace, according to her own statement, on 8 December 1542, the daughter of James V of Scotland and Mary of Lorraine, daughter of the Duke of Guise. On the death of her father, when she was six days old, Mary became Queen. To protect the child from 'Henry VIII's rough wooing' on behalf of his son Prince Edward, at the age of five she was sent to France to be educated and brought up at the French Court. When sixteen years of age, Mary married the Dauphin of France who in I 559 succeeded his father, Henry II, as Francis II. After the death of her husband from a cerebral abscess, in 1560 , Mary returned to Scotland to rule there under many difficulties including her religion as a Roman Catholic. On 29 July 1565 , she married Henry Stuart, Lord Darnley. It was an unfortunate marriage. Darnley treated Mary with neglect, conspired against her, and assisted at the murder of her secretary, David Rizzio, in her presence at Holyrood on 9 March ${ }_{15} 66$. On 19 June in Edinburgh Castle Mary gave birth to a son, afterwards James VI of Scotland and I of England. She was delivered by Margaret Houston, a midwife. The labour was prolonged and difficult. On 1o February 1567, the house Kirk o' Field where Darnley was convalescing from syphilis was blown up with gunpowder, 'the plot within a plot' (Mahon), and Darnley and his servant were murdered in the grounds by the Earl of Bothwell's men. Mary is now consider guiltless of the murder and the 'Casket Letters' which implicated her are regarded as forgeries." 
Sir Arthur MacNalty, K.C.B.

It is well established from contemporary evidence that the shock of Darnley's murder caused a complete temporary breakdown in Mary's mental and physical health. Bothwell took a base advantage of her irresponsible condition. $\mathrm{He}$ abducted the Queen, outraged her, and forced her to marry him by Protestant rites on I5 May. The marriage so incensed the Scottish nobles that they took up arms against her. The Queen's own army dispersed on I5 June at Carberry Hill; and Bothwell fled while Mary in a distraught and half-maniacal state surrendered to the Confederated Lords. She was imprisoned in Loch Leven Castle, where Nau stated she had a miscarriage of twins, her issue by Bothwell, followed by venous thrombosis of the left leg. Forced to abdicate in favour of her son, after nearly a year of captivity she escaped to be defeated by her halfbrother, the Earl of Murray, at Langside, I 3 May I 568 . Mary fled to the Solway, and took the unwise step of crossing to England to place herself under the protection of Queen Elizabeth. She became a State prisoner; and was imprisoned successively at Carlisle, Bolton, Tutbury, Wingfield, Coventry, Chatsworth, Sheffield, Buxton and Chartley. She endured captivity for nineteen years. At the age of 44, after a trial for participation in the Babington Conspiracy against the life of Elizabeth, on 8 February 1587, she was beheaded at Fotheringay Castle in Northamptonshire. She was first buried in Peterborough Cathedral, but in 1612 her son, King James I, had her remains moved to Westminster Abbey.

\section{The Illnesses of the Queen of Scots}

Maladies of Childhood. Queen Mary's father died at $3 \mathbf{I}$ of pulmonary tuberculosis and her mother of chronic nephritis and dropsy in 1560 at 44 , so her heredity was poor. But she was a healthy babe, as Sir Ralph Sadler, the English ambassador, reported to Henry VIII. In August 1543 she had chicken-pox, and in March 1548 a severe attack of measles at Dumbarton. She probably had rubella in March 1549. In September I550 she had an attack of the prevailing flux (? influenza); in the summer of 1566 dysentery after eating melon; in October an attack of malaria; in 1557 smallpox, when she was attended by Fernel, who, as she wrote to Elizabeth in 1562 , 'saved her beauty'. In May 1559 Sir Nicholas Throckmorton wrote: 'Assuredly the Scottish Queen in mine opinion looketh very ill on it; very pale and green, and therewith short breathed.' This is suggestive of chlorosis, for she also had fainting attacks. Her return to Scotland from France was delayed through illness.

Peptic Ulcer. Mary Stuart suffered from localized abdominal pain, attacks of vomiting and haematemesis for at least twenty-five years of her life. These are symptoms of peptic ulcer; and the recurrent vomiting and haematemesis suggest a gastric ulcer. The disease plainly declared itself when she was Queen of France; and, probably was a concomitant of the chlorosis from which she suffered as an adolescent. It was favoured by the hyperacidity of the gastric juice which occurs in chlorosis and by the physical and mental strain to which she was subjected from her youth onwards. Her swooning fits which have been ascribed to hysteria may often have been due to cerebral anaemia resulting 


\section{The Maladies of Mary Queen of Scots}

from the loss of large quantities of blood. The most serious attack she sustained was at Jedburgh in 1566 , when she seemed dead, 'her eyes closed, her mouth fast, and her feet and arms stiff and cold'. She was restored to life by her surgeon Arnault, 'a perfect man of his craft'.

Certainly [writes Armstrong Davison] it is difficult to imagine better treatment of a case of haemorrhagic shock, other than transfusion, than that which he employed. He bandaged very tightly her great toes, her legs from the ankle upwards, and her arms; then he poured some wine into her mouth, which he caused to be opened by force. He also gave a clyster (enema). Later, she vomited a great quantity of corrupt blood.

Her life was also in grave jeopardy after profuse haematemesis on several occasions.

Clinical Picture. The ulcer never perforated; it was probably situated on the posterior wall of the stomach, and most likely arose in a well-developed mucosa. This favoured rapid healing and accounts for the remissions between the attacks.

The clinical picture bears a close resemblance to the so-called 'Giant Innocent Gastric Ulcer' to which various writers (Lumsden, I950; Marshak et al., I 953; Reid, 1954; Jennings and Richardson, 1954) have drawn attention. S. L. Strange ${ }^{5}$ has studied this type of gastric ulcer, its behaviour and treatment in a series of forty-seven males and twenty-six females. He points out that these giant ulcers often present an atypical clinical picture and seriously endanger the life of the patient in spite of their 'innocent' character. This might have been so in Queen Mary's case. In fourteen patients in Strange's series the pain was not in the usual gastric area; and the Queen in some of her attacks of the 'spleen', as it was termed, suffered pain on the right side, although in most attacks it was on the left. Giant ulcers usually appear in later life than in the Queen's case, but they may originate at an earlier age. N. C. Tanner ${ }^{6}$ referring to massive haemorrhage from peptic ulcers said that in some cases death is almost certain, unless a hazardous operation is performed on a near moribund patient-compare Mary's critical condition at Jedburgh. In her days such an operation was impracticable. It says much for Queen Mary's courage, constitution and recuperative powers that she recovered from these repeated attacks, led an active and strenuous life in the remission periods, and that in the last four years of her life the ulcer, apparently, remained healed.

Chronic Rheumatism. A diagnosis of chronic rheumatism was deprecated by Osler ${ }^{7}$ who observed there was no uniformity in its usage, that it was applied without discrimination to all forms of arthritis and frequently to painful conditions of the muscles, fasciae and nerves as well as to those of the bones and joints. While recognizing the validity of these objections, $I$ have retained the term here as one which has been used by Queen Mary's biographers to describe her crippling and painful illness. From the particulars recorded, it appears to have been a mixed condition. The attacks of severe pain associated sometimes with fever, the remissions, especially under treatment at Buxton, and the eventual crippling suggest that the main malady was the 'classical' idiopathic 
type of rheumatoid arthritis, perhaps associated with fibrositis, and in the last year of her life with super-imposed osteo-arthritis causing degenerative lesions of the bones and joints.

The Queen's rheumatoid arthritis appears to have manifested itself in the cold and damp surroundings of Loch Leven during her imprisonment there in 1568. During her imprisonment in England the disease was generalized and progressive; and was favoured by the dampness and cold of some of her prisons, notably at Tutbury. At first, the symptoms of her gastric ulcer predominated. After 1573 her arthritis was severe, the joints, especially those of the upper and lower limbs, being swollen and painful, while in the last four years of her life arthritic symptoms and dropsy are the salient features in her illness. From I 58I she was permanently crippled and unable to walk without assistance. Sir Amyas Paulet gave her his arm to help her ascend the scaffold.

The Queen's malady was worse in cold and damp weather. Sunshine, open air and exercise improved her condition. Her physicians prescribed herbal remedies, decoctions, febrifuges, cinnamon water, unicorn's horn and tisanes. She had baths of wine for her general health. Queen Elizabeth, who scrutinized expense sheets closely, complained to Shrewsbury of the undue consumption of wine. Queen Mary used analgesic ointments of unknown composition for her gastric pains and for those in her limbs and joints. Her own testimony and the reports of her physicians and custodians clearly show the benefit she derived from drinking the waters and taking the baths at Buxton Spa. Indeed, Queen Mary is a striking example of the therapeutic efficiency of hydrotherapy. She took the 'cure' at Buxton in the years $1573,1575,1576,1577,1580,1581,1582$ and 1584 , together with a possible visit from Chatsworth in 1578 ; and on each of the eight or nine occasions derived much benefit from the treatment. The cure also abated the oedema of her legs.

Treatment at Buxton Well. The healing properties of the thermal waters of Buxton Well at a constant temperature of $82^{\circ}$ Fahrenheit for sufferers from chronic rheumatism and other maladies were recognized from Roman times. In the Middle Ages their efficacy was assigned to St. Anne to whom the well and adjacent chapel were dedicated. The walls of the chapel were covered with the crutches and sticks of the healed sufferers. The chapel was demolished in the reign of Henry VIII. The spa was the property of the Earl of Shrewsbury, Queen Mary's custodian. Here he built a large Tudor edifice with a wide portal arch and five separate gables springing from one central building, which bore a large clock tower. This was the great hall containing five baths, intended to serve separately for each sex, gentle and simple, with one special bath reserved for distinguished visitors which Queen Mary used. Each division of the bath hall was fitted with a drying and dressing-room. At no great distance was 'a very goodly house, four square, four stories high'. This was the Earl's own mansion, the Old Hall, where the Queen stayed. Farther off was the great hostel, or lodging for the patients of rank who came for the 'cure'; and situated among the rocks here and there were cottages which lodged the poorer sufferers. 'In a distant and magnificent way', Lord Shrewsbury took toll from the visitors 206 


\section{The Maladies of Mary Queen of Scots}

to his baths from which he derived a steady income. The season for taking the waters was then limited to the months of June, July and August.

Hither in these months came Dr. John Jones of King's Mede, Derby, to prescribe a medical regimen for the patients and to supervise and enforce it. At other times of the year he was at Bath for the same purpose, where his patron there was Henry Herbert, the second Earl of Pembroke. John Jones was a native of Wales. He studied at Oxford and Cambridge; and Wood conjectured that he took a degree in physic at the latter university (Cooper. Athenae Cantabr., 1,419). Miss C. M. Yonge described him in her novel, Unknown to History, as 'a dapper little figure with a short black cloak, a stiff round ruff and a square barrett cap, with a gold-headed cane in one hand and a paper in the other'. In this guise he would welcome Queen Mary and her retinue with a lengthy oration on the progress of Buxton and its healing qualities. In 1572 he had written and published a treatise on the waters-The Benefit of the ancient Bathes of Buckstones, which cureth most greevous sicknesses, never before published, London, I572, 4to.

For the Queen of Scots Dr. Jones prescribed the warm bath once or twice a day, followed by a draught of spiced milk; she had to drink measured quantities of the waters at regular intervals. Her dieting and the time of her rising, resting, recreation and exercise were carefully enjoined. The medical autocrat also prescribed certain medicines, rubbing and massage. A recreation, recommended by him for stretching the rheumatic joints of his patients, was playing at Trowle Madame. This was a sort of lawn bagatelle in which wooden balls were rolled into holes in a board placed on the turf, and Queen Mary enjoyed the game. On occasions, accompanied by Shrewsbury, she was permitted to ride in the neighbourhood; and once is said to have explored the dark cavern of Poole's Hole, situated at the foot of Grinlaw Hill, about half a mile west of Buxton, and to have penetrated as far as the group of stalactites, one of which is known as Mary, Queen of Scots' pillar.

Chronic Nephritis and Dropsy. In November 1582 Queen Mary had a serious illness at Sheffield after which she had oedema. In July 1584 after taking the 'cure' at Buxton in June, the Queen said in a letter to Castelnau that it had relieved her body of dropsical humours with which it had become surcharged. In January 1585 at Tutbury the Queen's foot was swollen and weak; and during the winter of $1585-6$ at Chartley the Queen's legs were considerably swollen. In 1586 with warmer weather she improved and the dropsy in her legs diminished. She was in much physical and mental distress at Tixall after the Babington plot, and was attended by Dr. Bourgoing and her apothecary. On returning to Chartley she took to her bed with dropsy and arthritis. Her legs were swollen at the time of her trial and at her execution.

In view of the death of her mother, Mary of Guise, from nephritis and dropsy it is possible that the Queen of Scots suffered from the same malady. She showed no symptoms of a failing heart, another cause of oedema and dropsy. Although in 1573 she was said to have chronic inflammation and 'induration of the liver', there is no evidence of a cirrhotic condition of the liver which is often accompanied by dropsy in the later stages of the disease. 
Queen Mary's Physicians

In Queen Mary's early childhood, presumably, she had Scottish physicians, but during her upbringing in France had French ones and thereafter preferred them. On her return to Scotland she brought Dr. Lusgerie, her chief physician, in her train. She sent him to attend Darnley in his illness at Glasgow in 1566. During part of her captivity in England she had Dr. Castellaune in attendance on her. In I 57 I from Sheffield Castle he wrote to Lord Burghley complaining of his royal patient's rigorous confinement and her lack of an apothecary and medicines. When Queen Mary was seriously ill Shrewsbury called in his own physicians to attend her. Queen Elizabeth on several occasions sent her physicians to her royal captive. For instance, after Mary had had a severe haematemesis in May I569, Thomas Francis, M.D. Oxon., F.R.G.P., and the learned Richard Caldwell, M.D. Oxon., F.R.C.P. (I5I3-84) saw her at Wingfield Manor House in April ${ }^{569}$, when she was very ill 'with shivering fits, vomiting and convulsions'. In the summer of the same year when Queen Elizabeth sent Dr. Francis to attend Shrewsbury, the Earl asked him to visit the Queen of Scots and prescribe for her. Dr. Francis was president of the College of Physicians in 1568 and Dr. Caldwell held the same high office in 1570.

In November 1570, at Sheffield, the Queen of Scots fell ill 'with the accustomed dolour of our side and a rheum'. Extreme pain, prolonged fainting attacks and sickness recurred with severity. Queen Elizabeth sent Edward Atslowe, M.D. Oxon., F.R.C.P. and James Good, M.D. Oxon., F.R.C.P. to attend her. Queen Mary must have exercised her wonted charm to enlist these physicians in her cause, for both of them were afterwards involved in plots for her liberation. Thomas Morgan wrote to the Queen of Scots:

I hear that Dr. Atslow was racked twice, almost to death, in the Tower, about the Earl of Arundell his matters, and intention to depart England.

After Dr. Atslowe's death in 1594, the Earl of Arundel settled a pension on his widow (Munk's Roll, I, 66). Concerning Dr. Good, Wood states: 'He was imprisoned in 1573 for holding secret correspondence by letters with Mary, Queen of Scots' (Munk's Roll, $\mathrm{I}, 5^{8}$ ).

The visits from the Queen of England's physicians, although appreciated by the Queen of Scots, were an embarrassment to her, because she was expected to pay handsome fees to them and often had little money available to do so. In I569 she borrowed $£ 966$ from the Duke of Norfolk out of which she gave $£ 66$ to Dr. Francis and Dr. Caldwell.

In 1575 Queen Mary's former physician, Dr. Lusgerie, was allowed to come from France to attend her. He accompanied her to Old Hall at Buxton, approved of Dr. Jones's regimen, and, in consultation with the latter supervised the Queen's 'cure'. He brought with him a young French apothecary to prepare and administer the medicines he prescribed. This apothecary was left behind when Lusgerie returned to France. Queen Mary's last physician was Dominique Bourgoing who was present at her execution and left an account in manuscript of her last days which was published by $M$. Chantelauze in 1878 .

208 
The execution of the Queen of Scots was a political blunder. Queen Elizabeth realized this, but the imminent threat of Spanish invasion, pressure by her ministers and Parliament, and the clamour of her Protestant subjects compelled her to sign the death warrant. Queen Mary's execution was also unnecessary, for in her serious condition of health she could not have lived long as both her English and French physicians realized. They do not seem to have been consulted on the question.

\section{REFERENGES}

I. Mahon, R.H. (1930). The Tragedy of Kirk o' Field. Cambridge University Press, Cambridge.

2. Davison, M. H. Armstrong (I955-56). 'The Maladies of Mary Queen of Scots and Her Husbands.' Scottish Society of the History of Medicine-Report of Proceedings, 19-34, Edinburgh.

3. MacNalty, A. S. (1960). Mary Queen of Scots: The Daughter of Debate. Christopher Johnson Publishers Ltd., London.

4. BLAck, J. B. (1959). The Reign of Elizabeth I. 2nd Ed., Clarendon Press, Oxford.

5. Strange, S. L. (1959). 'Giant Innocent Gastric Ulcer: its Behaviour and Treatment.' Brit. med. F., I, 476 .

6. Tanner, N. C. (1954). Postgrad. med. J., xxx, 448.

7. Osler, W. (1912). The Principles and Practice of Medicine, 8th Ed., 1142, New York and London. 